\title{
GASTROINTESTINAL BACTERIA IN ROHU, LABEO ROHITA (ACTINOPTERYGII: CYPRINIFORMES: CYPRINIDAE): SCANNING ELECTRON MICROSCOPY AND BACTERIOLOGICAL STUDY
}

\author{
Koushik GHOSH ${ }^{1 *}$, Moitreyee ROY ${ }^{1}$, Nibedita KAR ${ }^{1}$, and Einar RINGØ ${ }^{2,3}$ \\ ${ }^{1}$ Aquaculture Laboratory, Department of Zoology, The University of Burdwan, Golapbag, Burdwan, \\ West Bengal, India \\ ${ }^{2}$ Norwegian College of Fishery Science, Faculty of Biosciences, Fisheries and Economics, \\ University of Tromsø, No-9037 Tromsø, Norway \\ ${ }^{3}$ Aquaculture Protein Centre (a CoE), Department of Aquatic Medicine and Nutrition, \\ Norwegian School of Veterinary Medicine, P.O. Box 8146 Dep., No-0033 Oslo, Norway
}

Ghosh K., Roy M., Kar N., Ringø E. 2010. Gastrointestinal bacteria in rohu, Labeo rohita (Actinopterygii: Cypriniformes: Cyprinidae): scanning electron microscopy and bacteriological study. Acta Ichthyol. Piscat. 40 (2): 129-135.

Background. Fish gut bacteria may be used as probiotics for fish. Those occurring in the gastrointestinal (GI) tract of rohu, Labeo rohita (Hamilton, 1822), have not been sufficiently studied. This study was intended: to detect bacteria in the intestine of rohu by scanning electron microscopy (SEM); to evaluate the existence of heterotrophic, proteolytic, amylolytic, and cellulolytic bacteria in three different regions of the gut of rohu; and to identify more than $25 \%$ of the isolated gut bacteria by $16 \mathrm{~S}$ rRNA.

Materials and Methods. The GI tracts were removed and divided into three regions: foregut, midgut, and hindgut. Tissues used for SEM were fixed in glutaraldehyde, washed in heparinised saline, dehydrated in graded ethanol, fixed in amyl acetate, dried with liquid nitrogen, coated with gold, observed, and photographed. Homogenates of the intestinal segments were spread onto tryptic soy agar plates and selected nutrient media plates to determine heterotrophic, proteolytic, amylolytic, and cellulolytic bacterial populations, respectively. Of the 59 adherent bacterial strains isolated from the GI tract of rohu 16 isolates were tried for identification by 16S rRNA genes.

Results. Bacteria were observed to adhere to the gut enterocyte surfaces. Population level of enzyme-producing bacteria was higher in the midgut and hindgut regions than that observed in the foregut region. Furthermore, dense amylolytic and cellulolytic bacterial population in comparison to the proteolytic population was noticed in the GI tract of L. rohita. Highest density of the cellulolytic bacterial population in the hindgut region may indicate that fermentative degradation occurs in this part of the GI tract. Eleven adherent bacterial strains belonged to bacilli, 2 strains to Pseudomonas, 1 strain to Aeromonas, 1 strain was most closely related to Enterobacter, while 1 strain showed $<97 \%$ 16S rRNA sequence similarity in BLAST program was treated as unknown.

Conclusion. Autochthonous bacteria were present in the GI tract of rohu and that the autochthonous microbiota possess enzymatic activity that might be beneficial for the fish.

Keywords: SEM, gut bacteria, Labeo rohita, 16S rRNA

\section{INTRODUCTION}

The gut microbiota of marine and freshwater fish has been widely investigated during the last two decades (Cahill 1990, Ringø et al. 1995, Hansen and Olafsen 1999, Ringø and Birkbeck 1999, Ghosh et al. 2002a, Saha et al. 2006). It is a consensus view that dense bacterial population levels occurs in the gastrointestinal (GI) tract of fish (Austin 2002), and the gut microbiota can be defined as either autochthonous (indigenous) or allochtonous (transient) depending upon its ability to adhere and colonize the mucus layer in the digestive tract (Ringø and Birkbeck 1999, Ringø et al. 2003, 2007). Previous studies have isolated different bacteria species from the gut of one of the Indian major carps - rohu, Labeo rohita (Hamilton, 1822) and it has been suggested that the gut microbiota might be beneficial in the nutrition of the fish (Ghosh et al. 2002a, Kar and Ghosh 2008, Ray et al. 2010). Furthermore, attempts have also been made to use beneficial gut bacilli originally isolated from rohu as the probiotics for the fish (Ghosh et al. 2002b, 2003). One of the major criteria for selecting a probiotic strain is its ability to adhere and

\footnotetext{
* Correspondence: Dr. Koushik Ghosh, Aquaculture Laboratory, Department of Zoology, The University of Burdwan, Burdwan 713 104, West Bengal, India, phone: (+91) 943425 1606, fax: (+91 342) 263 4200, e-mail: kghoshbu@gmail.com or kghosh_bu@yahoo.co.in
} 
colonize the digestive tract of the host (Gatesoupe 1999, Vine et al. 2004, Pan et al. 2008). In this respect microbiological examination without use of electron microscopy observation might be speculative. Therefore, efforts have been made to demonstrate adherence of microorganisms in the GI tract of fish using scanning electron microscopy (SEM) and transmission electron microscopy (for review see, Ringø et al. 2003, 2007).

To the authors' knowledge, there is no information available on the association of gut bacteria in the GI tract of Indian major carps. Therefore, the aim of the presently reported study was to detect adherent gut microbiota in the GI tract of rohu by SEM. Furthermore, the presently reported study investigated the population level of heterotrophic, proteolytic, amylolytic, and cellulolytic bacteria in three different regions (foregut, midgut and hindgut) of the GI tract of rohu and identifies more than $25 \%$ of the isolated gut bacteria by $16 \mathrm{~S}$ rRNA genes.

\section{MATERIALS AND METHODS}

Post mortem examination. Fifteen live rohu, Labeo rohita $(431.66 \pm 4.56 \mathrm{~g})$ were collected from a local fish farm, transported in an oxygenated container to the Aquaculture Laboratory at Golapbag, Burdwan where the fish were acclimated for 10 days prior to the experiment. Prior to sampling for scanning electron microscopy (SEM) and isolation of the gut microbiota, the experimental fish were starved for $24 \mathrm{~h}$ to detect the autochthonous intestinal bacteria and to eliminate most of the allochthonous bacteria associated with digesta. After starvation, ten randomly sampled fish were anaesthetized and sacrificed according to guidelines given by the Institutional Ethical Committee. The GI tracts were removed aseptically and cut into three regions; foregut, midgut, and hindgut. The gut segments were opened by a longitudinal incision, transferred to sterile petri dishes and thoroughly washed 3 times with sterilized chilled $0.89 \%$ saline solution in order to remove the non-adherent (allochthonous) bacteria. Five segments of each section were pooled and analyzed for bacterial community. Pooled samples were used to avoid erroneous conclusions due to individual variations in gut microbiota, as described elsewhere (Ringø et al. 1995, Spanggaard et al. 2000, Ringø et al. 2006).

Scanning electron microscopy (SEM). SEM was carried out in order to detect bacteria associated to the intestine, the autochthonous microbiota. The gut segments of three fish were processed as follows; incised longitudinally to expose the mucosal surface, cut into small pieces and spread out on thin thermacol sheet with the mucosal surface uppermost. Thereafter, the segments were fixed in $2.5 \%$ glutaraldehyde in suitable buffer solution (cacodylate) for $30 \mathrm{~min}$, repeatedly washed in heparinised saline [ $2 \mathrm{~g}$ heparin (10 000-15 000 i.u.) and added $20 \mathrm{~mL}$ of $0.67 \% \mathrm{NaCl}$ solution] for 5 to $7 \mathrm{~min}$ to remove mucous partially. After rinsing in phosphate buffer $(\mathrm{pH} 7.2)$ the tissues were again fixed in glutaraldehyde for $18 \mathrm{~h}$ at $4^{\circ} \mathrm{C}$. Then the tissues were dehydrated in graded ethanol as follows: $50 \%$ (30 $\mathrm{min}), 70 \%$ (45 $\mathrm{min})$,
90\% (1 h) and absolute ethanol $(1 \mathrm{~h})$. Thereafter the tissues were given three consecutive changes (30 min each) in ethanol and amyl acetate solution in the ratio of $3: 1$, $2: 2$, and $1: 3$ respectively. Then the tissues were kept in pure amyl acetate for overnight. Critical point drying (CPD) was done (liquid nitrogen in vacuum medium). Then the tissues were coated with gold in IB ion coater and placed under scanning electron microscope (Hitachi S530) for observation and subsequent photography.

Isolation of autochthonous gut bacteria. Intestinal homogenates were made by adding 10 parts of sterilized $0.89 \%$ sodium chloride $(\mathrm{NaCl})$ solution as described elsewhere (Das and Tripathi 1991). Serial dilutions (up to $10^{-7}$ ) were made by mixing the homogenate solution with sterilized distilled water. Diluted samples of the different regions were spread onto Tryptic soy agar (TSA; Himedia Laboratories Pvt. Ltd., Mumbai, India) plates, peptone gelatin (PG) agar plates, starch (ST) agar plates and carboxymethylcellulose (CMC) agar plates to determine the heterotrophic, proteolytic, amylolytic, and cellulolytic bacterial populations, respectively (Ghosh et al. 2002a). The plates were inoculated with $200 \mu \mathrm{L}$ of the diluted samples (up to $10^{-7}$ ). Colonies were counted after $24 \mathrm{~h}$ of incubation at $37^{\circ} \mathrm{C}$ under aerobic conditions. Colonies having apparently different morphological appearance and coloration were isolated. Pure cultures were obtained by repeated streaking on TSA plates and maintained at $4^{\circ} \mathrm{C}$ in a refrigerator. The composition of the media used were as follows: TSA medium $\left(\mathrm{g} \cdot \mathrm{L}^{-1}\right)$ : casein $(15)$, papaic digest of soybean meal (5), $\mathrm{NaCl}$ (5), agar (20); GP medium $\left(\mathrm{g} \cdot \mathrm{L}^{-1}\right)$ : Lablemco (3), peptone (5), gelatin (4), agar (20); ST medium (g · L $\left.\mathrm{L}^{-1}\right)$ : $\left(\mathrm{NH}_{4}\right)_{2} \mathrm{SO}_{4}(2), \mathrm{KH}_{2} \mathrm{PO}_{4}$ (4), $\mathrm{Na}_{2} \mathrm{HPO}_{4}$ (4), $\mathrm{MgSO}_{4} \cdot 7 \mathrm{H}_{2} \mathrm{O}(0.2), \mathrm{CaCl}_{2}$ (0.001), $\mathrm{FeSO}_{4} \cdot 7 \mathrm{H}_{2} \mathrm{O}$ (0.004), starch (1.0), agar (15); CMC medium $\left(\mathrm{g} \cdot \mathrm{L}^{-1}\right)$ : ST medium with starch substituted by CMC.

Out of the 59 bacterial strains isolated from the GI tract of rohu, 16 isolates were randomly selected and tested for colony morphology, shape, Gram-reaction, endospore formation, and biochemical tests (nitrate, indol, methyl red, catalase and hydrolysis of starch, casein, and gelatin). Sixteen isolates including 4 isolates (Lr.M.19, Lr.M.48, Lr.H.23, Lr.H.52) with high enzymeproducing ability were further characterized by $16 \mathrm{~S}$ rRNA genes as described by Ringø et al. (2006). All sequences were analyzed and edited in BIOEDIT and blasted against sequences available in GenBank. Gut bacteria showing $<97 \%$ 16S rRNA sequence similarity in BLAST program was treated as unknown as they were below the similarity level for species delineation according to Stackebrandt and Goebel (1994).

\section{RESULTS}

Bacteria associated to rohu intestine. In Fig. 1 of the foregut region of rohu small pores were observed. The origin of these small pores is not known, but the holes might be due to emptying goblet cells (mucus producing cells), lipid droplets loosened during preparation or transit paths of deeply embedded bacteria. The white aggre- 
gates noticed in Fig. 1 are probably bacterial colonies and indicate that gut bacteria were capable to adhere the enterocytes surfaces of L. rohita. Figs. 2 and 3 depict association of bacterial colony at the connection of adjacent enterocytes and individual bacterium respectively at foregut region. SEM evaluation revealed that bacteria present in the GI tract were rod shaped; short or long (Fig. 4). Along with colonization capacity the dividing stages of bacteria indicated their ability to propagate in the GI tract (Fig. 5). Furthermore, SEM investigation also showed that the bacterial colonies attached in the intestinal fold were associated with mucous (Fig. 6), and the attachment of bacteria was clearly visible in the mucous removed intestinal folds of the midgut region (Figs. 7, 8).

Isolation of intestinal bacteria. Analysis of the bacterial community in the three different gut regions of L. rohita showed that population level of enzyme-producing bacteria was significantly higher in the midgut and hindgut regions than that noticed for the foregut region (Table 1). Generally, higher population levels of amylolytic and cellulolytic bacteria were detected compared to proteolytic bacteria and the population level of cellulolytic bacteria was highest in the hindgut region (Table 1). Out of 59 gut isolates 16 isolates characterized by morphological and biochemical tests revealed that most of the isolates were rod-shaped. The rod-shaped form noticed by

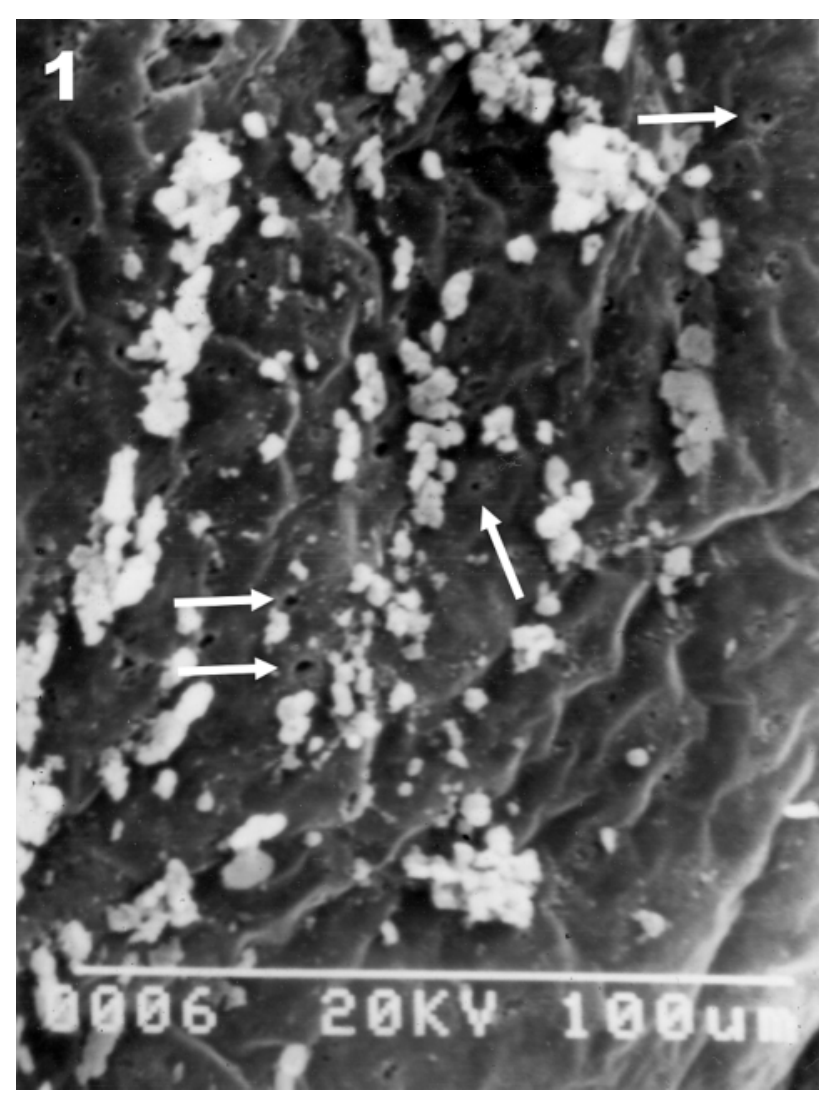

Fig. 1. Scanning electron micrograph of the foregut of Labeo rohita showing small pores (white arrow); White aggregates are formed probably due to bacterial colony $(\times 2000)$; Mucus is partially removed during preparation microscopy was in accordance with that observed by SEM. Identification of the 16 gut isolates by $16 \mathrm{~S}$ rRNA are displayed in Table 2. Of the 4 bacterial species identified from the foregut of rohu 3 isolates were most closely related to bacilli and one isolate could be assigned to Enterobacter. Six adherent isolates from midgut of rohu were identified by partial sequencing of the $16 \mathrm{~S}$ rRNA genes. Two isolates shared high similarity to Bacillus cereus, one isolate was most closely related to Bacillus subtilis, one to Bacillus sp. HRB-1C, while two isolates could be assigned to Pseudomonas sp. adx-1 in the BLAST database search in GenBank. Four of the strains isolated from the hindgut were most closely related to Bacillus, one belonged to Aeromonas veronii, while one isolate could not be assigned to a genus or species in the BLAST database search in GenBank.

\section{DISCUSSION}

Electron microscopy examinations of the gut have been suggested as an important tool for investigating the microbial ecology of fish and numerous reports have been published during the last three decades describing bacteria attached to mucosa and microvilli of the intestine (for review see, Ringø et al. 2003; 2007). Previous scanning electron microscopy (SEM) and transmission electron microscopy (TEM) evaluations of fish gut have demonstrated rod-shaped bacteria associated between the microvilli in Atlantic wolfish, Anarhichas lupus (see Hellberg and Bjerkas 2000) and coccoid and rod-shaped bacteria associated with the surface of gut enterocytes of Arctic charr, Salvelinus alpinus L. (see Ringø et al. 2001). The presently reported study is the first one demonstrating adherent bacteria on the gut enterocytes surfaces of $L$. rohita. The bacterial community may remain associated with the folds of the intestinal villi wrapped by mucous. A micrograph demonstrating the dividing bacterium may also suggest that these intestinal bacteria also propagate within the intestine (Fig. 5). Microbial cultivation of intestinal bacteria in rohu seems to be dominated by the rod shaped, bacilli like bacteria, and this finding was confirmed by SEM. Previous reports have also documented the presence of bacilli within the digestive tract of L. rohita (see: Ghosh et al. 2002a, Kar et al. 2008, Roy et al. 2009, Mondal et al. 2010, Ray et al. 2010). In the presently reported study, 11 of the 16 isolates identified by $16 \mathrm{~S}$ rRNA belonged to bacilli.

To the authors' knowledge, B. subtilis has previously been reported in the intestinal tract of flathead grey mullet, Mugil cephalus L. (see Nagvenkar et al. 2006); Atlantic salmon, Salmo salar L. (see Ringø et al. 2008); and bata, Labeo bata (see Mondal et al. 2010). In the presently reported study, we identified one autochthonous isolate from the foregut which showed similarity to Bacillus subtilis strain BE-91 described by Liu et al. (unpublished data, National Center for Biotechnology Information (NCBI), http://www.ncbi.nlm.nih.gov/), one isolate (Lr.M.19) showed high similarity to B. subtilis strain AF0907 described by Wang et al. (unpublished data, NCBI) while one isolate (Lr.H.52) was most closely related to B. subtilis 

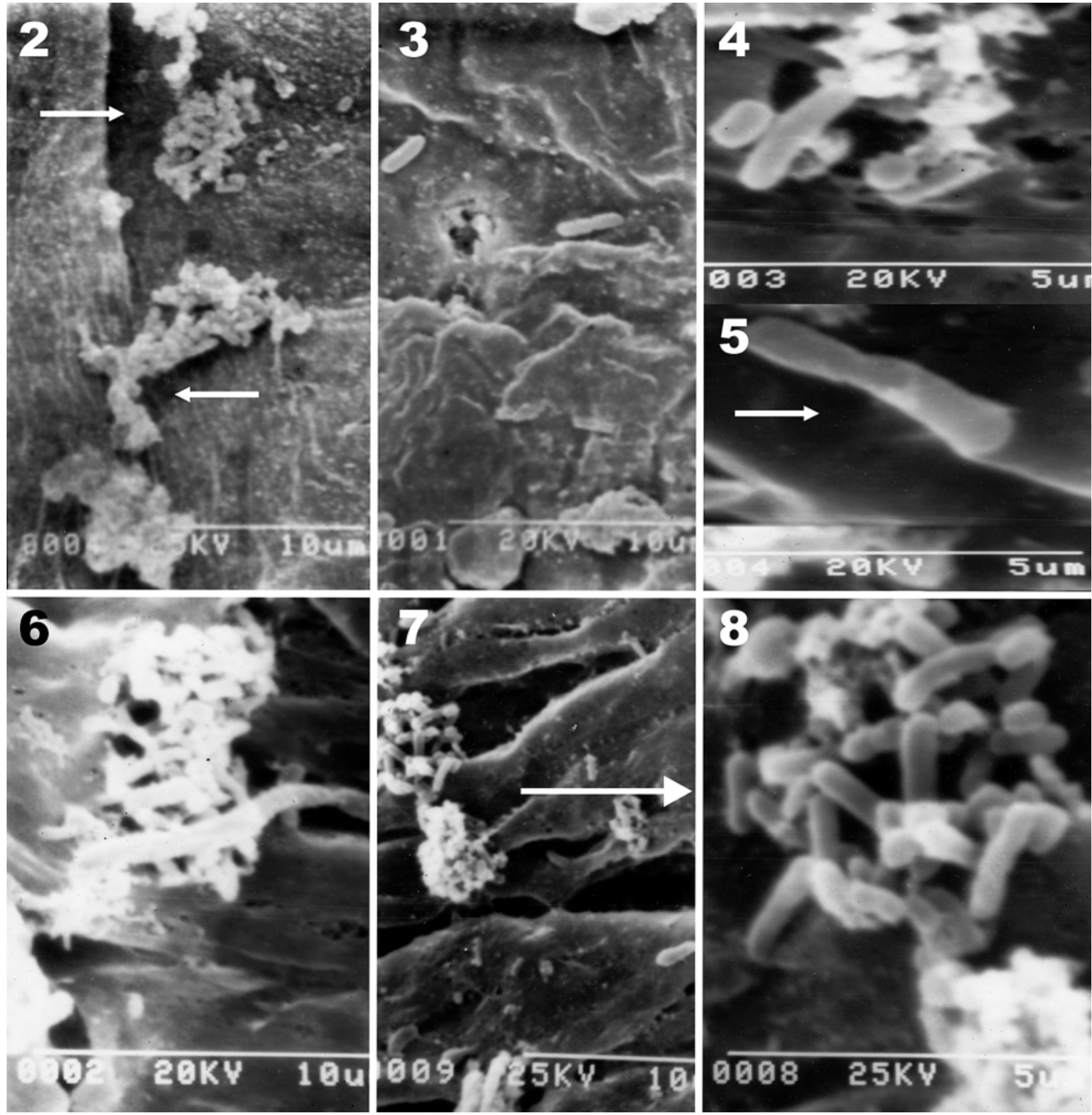

Fig. 2-8. Association of bacteria at different regions of the gut in Labeo rohita; Fig. 2. Bacterial colony at the foregut region; Border between adjacent enterocytes is visible; Fig. 3. Bacterial cells at the foregut region of $L$. rohita $(\times 1000)$; Fig. 4. Short and long rod shaped bacteria; Fig. 5. Bacterial cell at vegetative mode of reproduction in the midgut region; Fig. 6. Bacterial colony wrapped by mucus at the midgut region; Enterocytes/intestinal folds are not clearly visible due to mucus covering; Fig. 7. Bacterial colony associated with the intestinal folds at the midgut region; Fig. 8. Enlarged view

strain R2-1 isolated from mushroom waste in Korea (Jee et B. cereus-like bacterial strains showed high similarity to al. unpublished data, NCBI). It is worth to notice that iso- B. cereus strain ZQP-3, previously described in a study of lates Lr.M.19 and Lr.H.52 isolated from midgut and denitrifying phosphorus accumulating bacteria (Zhang et hindgut, respectively displayed high enzymatic activity. al. unpublished data, NCBI), two stains were closely To date, three studies has reported the presence of Bacillus related to B. cereus strain SU-6 (Samrot et al. unpublished cereus and then the bacteria was isolated from the gut of data, NCBI), while one strain could be assigned to rohu fingerlings (Ghosh et al. 2002a), intestine of flat- B. cereus strain AK1 as described by Annamalai et al. head grey mullet (Esakkiraj et al. 2009) and distal intes- (unpublished data, NCBI). The isolates showing high simtine of an Indian major carp — catla, Catla catla (see Ray ilarity to B. cereus strain SU-6 displayed high enzymatic et al. 2010). In the presently reported study, two adherent activity. Ormeno-Orrillo and Martinez-Romero (unpub- 
Table 1

Aerobic heterotrophic bacterial count in different regions of the gastrointestinal tract of Labeo rohita

\begin{tabular}{lcccc}
\hline \multirow{2}{*}{ Regions of the DI tract } & \multicolumn{4}{c}{ CFU g $^{-1}$ digestive tract of fish $\left(\times 10^{7}\right)$} \\
\cline { 2 - 5 } & Total heterotrophic & Proteolytic & Amylolytic & Cellulolytic \\
\hline Foregut & $7.33 \pm 0.56^{\mathrm{a}}$ & $0.14 \pm 0.06^{\mathrm{a}}$ & $1.52 \pm 0.20^{\mathrm{a}}$ & $0.22 \pm 0.07^{\mathrm{a}}$ \\
Midgut & $9.62 \pm 0.14^{\mathrm{c}}$ & $0.74 \pm 0.07^{\mathrm{b}}$ & $4.36 \pm 0.36^{\mathrm{b}}$ & $0.62 \pm 0.06^{\mathrm{b}}$ \\
Hindgut & $8.51 \pm 0.29^{\mathrm{b}}$ & $0.72 \pm 0.07^{\mathrm{b}}$ & $4.20 \pm 0.16^{\mathrm{b}}$ & $1.67 \pm 0.05^{\mathrm{c}}$ \\
\hline
\end{tabular}

Values with same superscripts in the same column are not significantly different $(P<0.05)$.

Identification of bacterial strains isolated from the gastrointestinal tract of Labeo rohita

Table 2 with partial sequence of $16 \mathrm{~S}$ rRNA genes referenced to accession No. in GenBank

\begin{tabular}{lcccc}
\hline Isolate & Isolated from & Closest relative (obtained from BLAST search) & $\begin{array}{c}\text { Similarity } \\
(\%)\end{array}$ & Accession no. \\
\hline Lr.F.03 & $\mathrm{F}$ & Enterobacter cloacae & 97 & EF059865 \\
Lr.F.08 & $\mathrm{F}$ & Bacillus subtilis strain BE-91 & 98 & GQ845009 \\
Lr.F.11 & $\mathrm{F}$ & Bacillus licheniformis strain CrK21 & 98 & GQ503331 \\
Lr.F.31 & $\mathrm{F}$ & Bacillus cereus strain ZQP3 & 98 & GU384226 \\
Lr.M.13 & $\mathrm{M}$ & Bacillus sp. HRB-1C & 97 & DQ979413 \\
Lr.M.14 & $\mathrm{M}$ & Pseudomonas sp. adx-1 & 99 & FJ169466 \\
Lr.M.19 & $\mathrm{M}$ & Bacillus subtilis strain AF0907 & 98 & GU272021 \\
Lr.M.21 & $\mathrm{M}$ & Pseudomonas sp. adx-1 & 98 & FJ169466 \\
Lr.M.46 & $\mathrm{M}$ & Bacillus cereus strain ZQP3 & 99 & GU384226 \\
Lr.M.48 & $\mathrm{M}$ & Bacillus cereus strain SU-6 & 97 & GU395988 \\
Lr.H.22 & $\mathrm{H}$ & Aeromonas veronii strain MRM0908 & 98 & GQ983054 \\
Lr.H.23 & $\mathrm{H}$ & Bacillus cereus strain SU-6 & 99 & GU395988 \\
Lr.H.27 & $\mathrm{H}$ & Bacillus cereus strain AK1 & 97 & FJ870664 \\
Lr.H.30 & $\mathrm{H}$ & Unknown* & $<97$ & EU852929 \\
Lr.H.52 & $\mathrm{H}$ & Bacillus subtilis strain R2-1 & 99 & FJ889057 \\
Lr.H.55 & $\mathrm{H}$ & Bacillus amyloliquefaciens strain Bac3M7 & 99 & \\
\hline
\end{tabular}

*strain Lr.H.30 was treated as unknown as similarity was $<97 \%$ in the BLAST database search in the GenBank; F = foregut, $\mathrm{M}=$ midgut, $\mathrm{H}=$ hindgut.

lished data, NCBI) investigated plant-growth-promoting activities and phylogenetic affiliation of antagonistic Bacillus associated with potato rhizosphere in Andean soils of Peru. In this study, the authors presented information on Bacillus amyloliquefaciens strain Bac3M7. One of our strains shared $99 \%$ similarity with B. amyloliquefaciens strain Bac3M7. A study investigating enzyme-producing bacteria from foregut and hindgut of bata (Mondal et al. 2010) present a description of Bacillus licheniformis. In another study Bacillus licheniformis strains LF1 and LH1 were reported from the foregut and the hindgut regions of rohu, respectively (Roy et al. 2009). In the presently reported study, one adherent strain isolated from the foregut showed $98 \%$ similarity to B. licheniformis strain CrK21 by Rizvi et al. (unpublished data, NCBI). Information about $16 \mathrm{~S}$ rRNA sequence of Bacillus sp. HRB-1C is available (Balestrazzi et al. 2008). In this study, the authors showed $98 \%$ similarity of Bacillus sp. HRB-1C to Bacillus pumilus sau611-26. Strain Lr.M.13 isolated in the presently reported study shared $97 \%$ similarity to Bacillus sp. HRB-1C.
Aeromonas veronii is a well known fish pathogenic bacteria (Orozova et al. 2009). However to the authors' knowledge no information is available about $A$. veronii presence in the alimentary tract of fish. The Lr.H.22 strain isolated from the hindgut in the presently reported study showed high similarity to $A$. veronii strain MRM0908 described by Pan and Shen (unpublished data, NCBI). Iversen et al. (2007) present partial sequence of $16 \mathrm{~S}$ rRNA gene of Enterobacter cloacae accession no. EF059865 in a study evaluating 321 strains from the culture collections at Nestlè Research Centre, Lausanne, Switzerland. To our knowledge, only one investigation results have been published on Pseudomonas spp. in the digestive tract of rohu (Kumari et al. 2001). In the presently reported study two isolates (Lr.M.14 and Lr.M.21) showed high similarity to Pseudomonas sp. adx1 accession no. FJ169466 previously described by Xin (unpublished data, NCBI).

In the presently reported study, population levels of heterotrophic, proteolytic, amylolytic, and cellulolytic bacteria were evaluated in three different regions of the 
GI tract of L. rohita. As the fish were starved for $24 \mathrm{~h}$ and their digestive tracts thoroughly washed with sterilized chilled $0.89 \%$ saline prior isolation of bacteria, we suggest that these bacteria belong to the autochthonous microbiota. This hypothesis was confirmed by SEM investigations. Several investigators have reported the presence of enzyme producing bacteria in the digestive tract of L. rohita (see Bairagi et al. 2002, Ghosh et al. 2002a, Kar and Ghosh 2008, Kar et al. 2008, Mondal et al. 2008, 2010, Ray et al. 2010, this study). Our study reports four potent enzyme producing bacteria in the digestive tract of rohu, 2 isolates (Lr.M.48 and Lr.H.23) were most closely related to $B$. cereus strain SU-6, while isolate Lr.M.19 and Lr.H.52 showed high similarity to B. subtilis strain AF0907 and B. subtilis strain R2-1, respectively. Moreover, in the presently reported study the bacterial population level in the different regions of the GI tract of rohu showed higher numbers of heterotrophic bacterial populations in midgut and hindgut regions compared to the foregut region. Our results are in agreement with the results of Mondal et al. (2008) who reported higher heterotrophic population levels in the hindgut than that detected in the foregut.

In the presently reported investigation, amylolytic and cellulolytic bacterial populations were higher compared to the proteolytic population. Colonization of amylolytic and cellulolytic bacteria at such high rate may be due to the fact that L. rohita, though omnivorous, mostly prefer plant materials as their food. It was also revealed that the cellulolytic bacterial population was highest in the hindgut region compared to the foregut and midgut regions. This may indicate the possibility of the fermentative degradation of the plant material in this part of the GI tract in assistance with the highly colonized cellulolytic bacteria. The potential beneficial effects of those bacteria isolated in the presently reported study are worth to explore in further investigations.

\section{CONCLUSIONS AND FUTURE PERSPECTIVES}

The results of the presently reported study provide evidence that autochthonous bacteria exist in the gastrointestinal tract of Labeo rohita, and further verify the existence of the enzyme-producing bacteria in the gut microbiota. The presently reported study is the first one using electron microscopy to demonstrate gut microbiota of rohu and we suggest that these autochthonous bacteria might have a beneficial potential that has to be evaluated in future L. rohita investigations. As the antimicrobial potential of the beneficial gut bacteria isolated from rohu to inhibit potential pathogens has not been evaluated we recommend that this topic should be given high priority in future studies together with challenge studies.

Difficulties in analyzing the complexity of bacterial community by classic methods of cultivation have necessitated the development of molecular methods. In order to overcome these problems, various methods such as denaturing gradient gel electrophoresis (DGGE), fluorescence in situ hybridization, temporal temperature gradient elec- trophoresis and clone libraries have been developed in order to circumvent the need for isolation. Therefore, in future studies we will use DGGE when evaluating the bacterial gut community in rohu.

\section{ACKNOWLEDGEMENTS}

Sincere thanks to Dr. N. Hazra, Head, Department of Zoology, The University of Burdwan; the Department of Science and Technology, New Delhi (FIST programme in the department) and the University Grants Commission, New Delhi, India [Project F. No. 32-523/2006(SR)] for providing research facilities and partial financial support. The authors are grateful to Dr. S. Chakrabarti of the USIC, The University of Burdwan for technical support and to Dr. R.N. Roy for rendering help in preparing the manuscript.

\section{REFERENCES}

Austin B. 2002. The bacterial microflora of fish. The Scientific World Journal 2 (3): 558-572. DOI: 10.1100/tsw.2002.137

Bairagi A., Ghosh K.S., Sen S.K., Ray A.K. 2002. Enzyme producing bacterial flora isolated from fish digestive tracts. Aquaculture International 10 (2): 109-121. DOI: $10.1023 / \mathrm{A}: 1021355406412$.

Balestrazzi A., Bonadei M., Zelasco S., Quattrini E., Calvio C., Galizzi A., Carbonera D. 2008. Recovery of useful traits from isolates inhabiting an agricultural soil cultivated with herbicide-resistant poplars. Canadian Journal of Microbiology 54 (3): 201-208. DOI: 10.1139/W07-136.

Cahill M.M. 1990. Bacterial flora of fishes: A review. Microbial Ecology 19 (1): 21-41. DOI: $10.1007 / \mathrm{BF} 02015051$.

Das K.M., Tripathi S.D. 1991. Studies on the digestive enzymes of grass carp, Ctenopharyngodon idella (Val.). Aquaculture 92: 21-32. DOI: 10.1016/0044-8486(91)90005-R

Esakkiraj P., Immanuel G., Sowmya S.M., Iyapparaj P., Palavesam A. 2009. Evaluation of protease-producing ability of fish gut isolate Bacillus cereus for aqua feed. Food Bioprocess and Technology 2 (4): 383-390. DOI: $10.1007 / \mathrm{s} 11947-007-0046-6$.

Gatesoupe F.J. 1999. The use of probiotics in aquaculture. Aquaculture 180 (1-2): 147-165. DOI: 10.1016/S0044-8486(99)00187-8.

Ghosh K., Sen S.K., Ray A.K. 2002a. Characterization of bacilli isolated from the gut of rohu, Labeo rohita, fingerlings and its significant in digestion. Journal of Applied Aquaculture 12 (3): 33-42. DOI: 10.1300/J028v12n03 04.

Ghosh K., Sen S.K., Ray A.K. 2002b. Growth and survival of rohu, Labeo rohita (Hamilton) spawn fed diets supplemented with fish intestinal microflora. Acta Ichthyologica et Piscatoria 32 (1): 83-92.

Ghosh K., Sen S.K., Ray A.K. 2003. Supplementation of an isolated fish gut bacterium, Bacillus circulans, in formulated diets for rohu, Labeo rohita, fingerlings. The Israeli Journal of Aquaculture - Bamidgeh 55 (1): 13-21.

Hansen G.H., Olafsen J.A. 1999. Bacterial interactions in early life stages of marine cold water fish. Microbial Ecology 38 (1): 1-26. DOI: $10.1007 / \mathrm{s} 002489900158$. 
Hellberg H., Bjerkas I. 2000. The anatomy of the stomach, oesophagus and intestine in common wolfish (Anarhichas lupus L.), a basis for diagnostic work and research. Acta Veterinaria Scandinavica 41: 283-297.

Iversen C., Lehner A., Mullane N., Bidlas E., Cleenwerck I., Marugg J., Fanning S., Stephan R., Joosten H. 2007. The taxonomy of Enterobacter sakazakii: proposal of a new genus Cronobacter gen. nov. and descriptions of Cronobacter sakazakii comb. nov. Cronobacter sakazakii subsp. sakazakii, comb. nov., Cronobacter sakazakii subsp. malonaticus subsp. nov., Cronobacter turicensis sp. nov., Cronobacter muytjensii sp. nov., Cronobacter dublinensis sp. nov. and Cronobacter genomospecies. BMC Evolutionary Biology 7: 64.

DOI: $10.1186 / 1471-2148-7-64$.

Kar N., Ghosh K. 2008. Enzyme producing bacteria in the gastrointestinal tracts of Labeo rohita (Hamilton) and Channa punctatus (Bloch). Turkish Journal of Fisheries and Aquatic Sciences 8 (1): 115-120.

Kar N., Roy R.N., Sen S.K., Ghosh K. 2008. Isolation and characterization of extracellular enzyme producing bacilli in the digestive tracts of rohu, Labeo rohita (Hamilton) and Murrel, Channa punctatus (Bloch). Asian Fisheries Science 21 (4): 421-434.

Kumari S., Prasad B.N., Kumari G., Quasim A., Sinha B.K., Singh J.N. 2001. Microbiological quality of fish, rohu marketed in Patna and its public health significance. Journal of Food Science and Technology 38 (6 ): 607-608.

Mondal S., Roy T., Ray A.K. 2010. Characterization and identification of enzyme-producing bacteria isolated from the digestive tract of bata, Labeo bata. Journal of the World Aquaculture Society 41 (3): 369-377. DOI: $10.1111 /$ j.1749-7345.2010.00378.x.

Mondal S., Roy T., Sen S.K., Ray A.K. 2008. Distribution of enzyme-producing bacteria in the digestive tracts of some freshwater fish. Acta Ichthyologica et Piscatoria 38 (1): 1-8. DOI: 10.3750/AIP2008.38.1.01.

Nagvenkar G.S., Nagvenkar S.S., Rivonker C.U., Sangodkar U.M.X. 2006. Microbial diversity and enzyme production in mullet Mugil cephalus L. (Pisces) along Goa, west coast of India. Indian Journal of Marine Sciences 35 (1): 36-42.

Orozova P., Barker M., Austin D.A., Austin B. 2009. Identification and pathogenicity to rainbow trout, Oncorhynchus mykiss (Walbaum), of some aeromonads. Journal of Fish Diseases 32 (10): 865-871. DOI: 10.1111/j.1365-2761.2009.01065.x.

Pan X., Wu T., Zhang L., Song Z., Tang H., Zhao Z. 2008. In vitro evaluation on adherence and antimicrobial properties of a candidate probiotic Clostridium butyricum CB2 for farmed Fish. Journal of Applied Microbiology 105 (5): 1623-1629. DOI: 10.1111/j.1365-2672.2008.03885.x.

Ray A.K., Roy T., Mondal S., Ringø E. 2010. Identification of gut-associated amylase, cellulase and protease-producing bacteria in three species of Indian major carps. Aquaculture Research 41 (10): 1462-1469. DOI: $10.1111 /$ j.1365-2109.2009.02437.x.

Ringø E., Birkbeck T.H. 1999. Intestinal microflora of fish larvae and fry. Aquaculture Research 30 (2): 73-93.
Ringø E., Lødemel J.B., Myklebust R., Kaino T., Mayhew T.M., Olsen R.E. 2001. Epithelium-associated bacteria in the gastrointestinal tract of Arctic charr (Salvelinus alpinus L.). An electron microscopical study. Journal of Applied Microbiology 90 (2): 294-300. DOI: 10.1046/j.1365-2672.2001.01246.x.

Ringø E., Myklebust R., Mayhew T.M., Olsen R.E. 2007. Bacterial translocation and pathogenesis in the digestive tract of larvae and fry. Aquaculture 268 (1-4): 251-264. DOI: 10.1016/j.aquaculture.2007.04.047.

Ringø E., Olsen R.E., Mayhew T.M., Myklebust R. 2003. Electron microscopy of the intestinal microflora of fish. Aquaculture 227 (1-4): 395-415. DOI: 10.1016/j.aquaculture.2003.05.001.

Ringø E., Sperstad S., Kraugerud O.F., Krogdahl Å. 2008. Use of 16S rRNA gene sequencing analysis to characterise culturable intestinal bacteria in Atlantic salmon (Salmo salar) fed diets with cellulose or non-starch polysaccharides from soy. Aquaculture Research 39 (10): 1087-1100. DOI: $10.1111 /$ j.1365-2109.2008.01972.x.

Ringø E., Sperstad S., Myklebust R., Mayhew T.M., Olsen R.E. 2006. The effect of dietary inulin on aerobic bacteria associated with hindgut of Arctic charr (Salvelinus alpinus L.). Aquaculture Research 37 (9): 891-897. DOI: 10.1111/j.1365-2109.2006.01509.x.

Ringø E., Strøm E., Tabachek J.-A. 1995. Intestinal microflora of salmonids: a review. Aquaculture Research 26 (10): 773-789. DOI: 10.1111/j.1365-2109.1995.tb00870.x.

Roy T., Mondal S., Ray A.K. 2009. Phytase-producing bacteria in the digestive tracts of some freshwater fish. Aquaculture Research 40 (3): 344-353.

DOI: $10.1111 / \mathrm{j} .1365-2109.2008 .02100 . x$.

Saha S., Roy R.N., Sen S.K., Ray A.K. 2006. Characterization of cellulase-producing bacteria from the digestive tract of tilapia, Oreochromis mossambica (Peters) and grass carp, Ctenopharyngodon idella (Valenciennes). Aquaculture Research 37 (4): 380-388.

DOI: $10.1111 /$ j.1365-2109.2006.01442.x.

Spanggaard B., Huber I., Nielsen J., Nielsen T., Appel K.F., Gram L. 2000. The microflora of rainbow trout intestine: a comparison of traditional and molecular identification. Aquaculture 182 (1-2): 1-15.

DOI: $10.1016 / \mathrm{S} 0044-8486(99) 00250-1$.

Stackebrandt E., Goebel B.M. 1994. Taxonomic note: A place for DNA-DNA reassociation and 16S rRNA sequence analysis in the present species definition in bacteriology. International Journal of Systematic Bacteriology 44: 846-849. DOI: 10.1099/00207713-44-4-846.

Vine N.G., Leukes W.D., Kaiser H., Daya S., Baxter J., Hecht T. 2004. Competition for attachment of aquaculture candidate probiotic and pathogenic bacteria on fish intestinal mucus. Journal of Fish Diseases 27 (6): 319-326. DOI: $10.1111 /$ j.1365-2761.2004.00542.x.

Received: 9 June 2009

Accepted: 8 May 2010

Published electronically: 15 December 2010 